\title{
Socioeconomic Impacts of Climatic Change on Paddy Cultivation: An Empirical Investigation in Malaysia
}

\author{
Md. Mahmudul Alam* \\ National University of Malaysia \\ Selangor, Malaysia \\ Email: rony000@gmail.com \\ Chamhuri Siwar \\ Universiti Kebangsaan Malaysia \\ Selangor, Malaysia \\ Rafiqul Islam Molla \\ Multimedia University \\ Melaka, Malaysia \\ Mohd Ekhwan bin Toriman \\ Universiti Kebangsaan Malaysia (UKM) \\ Selangor, Malaysia \\ Basri Talib \\ Universiti Kebangsaan Malaysia \\ Selangor, Malaysia
}

* Corresponding Author

\section{Citation Reference:}

Alam, M.M., Siwar, C., Molla, R.I., Mohd Ekhwan, T., and Talib, B. 2010. Socioeconomic Impacts of Climatic Change on Paddy Cultivation: An Empirical Investigation in Malaysia, Journal of Knowledge Globalization, Vol. 3(2), pp.71-84. Available at $<$ http://journals.sfu.ca/jkg/index.php/journal/article/view/57/44>.

This is a pre-publication copy.

The published article is copyrighted by the publisher of the journal. 


\title{
Socioeconomic Impacts of Climatic Change on Paddy Cultivation: An Empirical Investigation in Malaysia
}

\begin{abstract}
The changing natures of climatic factors have different impacts on agriculture based on areas, periods and crops. Farmers are the most vulnerable group who are affected both directly and indirectly through climatic changes. In the study area in Malaysia, climatic changes have adverse impacts on farmers. Due to climatic change productivity and profitability of paddy cultivation have declined in the Integrated Agricultural Development Area, North-West Selangar. Farmers perceive that paddy cultivation is no longer profitable due to low productivity as a result of climatic changes. They now prefer full-time to part-time engagement in paddy cultivation. Heavy government subsidy and encouragement are not enough; it requires increase in productivity and profitability of paddy cultivation for making its viable and sustainable sector. All efforts of mitigation and adaptation must be pursued to counter the adverse impacts of climatic changes and increase the productivity of paddy cultivation in the area. It is observed that there is a high degree of income inequality among the paddy farmers in the study area.
\end{abstract}

Key words: Climatic Change; Income Equality, Health Hazard; Agriculture; Paddy; Malaysia

\section{INTRODUCTION}

Climate is expressed and described by the factors like the amount of rainfall, sunshine hours, temperature, relative humidity and length of flood or drought periods. The impacts of climate change are not limited to any geographical boundary or timeframe. Some of the aspects are long term and related to national or international security such as, soil erosion, chemical poisoning or nuclear waste (Daly and Cobb 1990), and some issues are related to daily quality of life such as, water pollution, shortage of food or resources (Homer-Dixon 1992). The combined effects of these issues are difficult to predict such as, natural and environmental catastrophes in recent times- floods, landslides, long periods of drought etc (United Nations 1997), which also cause vulnerability in terms of yield, farm profitability, and hunger (Reilly 1999, Schimmelpfenning 1996). Climate change, therefore, affect various areas, sectors and stakeholders in various ways (Klein et al. 2005).

However, since agriculture is heavily dependent of climate, changes in the climatic factors result in year-to-year and area-to-area variability of crop production which largely affects the social and economic status of the livelihood and health status of the farming community. Climate change therefore adversely affect agriculture and all its relevant stakeholders. Among all the stakeholders farmer community is the most vulnerable group due to their full dependency on agriculture. Many socioeconomic factors are affecting by climate change that vary from place to place based on economic, social, political and environmental condition of the locality. This empirical paper deals the direct impacts of climate change on farmers in case of Malaysia. This paper also provides policy options for better cope with the unpredictable movement of the factors of climate change. 
Impacts of climate change on agriculture vary from period to period, area to area, and country to country based on economic, social, political, and environmental condition of the locality. Like other countries in this region climate change has adversely affected Malaysia's agriculture in a variety of ways in different parts of the country. Its fisheries, forestry, and livestock and crop cultivations have been seriously affected by the climate change. This paper attempts to identify and analyse the nature and magnitude of socio-economic impacts of the climate change on farmers in the integrated agricultural development area of North West Selangor in Malaysia.

\section{METHODOLOGY}

Data used in this paper were obtained from a research project: The economics of climate change: Economic dimensions of climate change, impacts and adaptation practices in agriculture sector: Case of paddy sector in Malaysia, at the Institute for Environment and Development (LESTARI) of National University of Malaysia (UKM) (Alam et al. 2010a). Under that project data were collected through a sample survey of paddy producing farmers in the area of Integrated Agricultural Development Area (IADA), North West Selangor, Malaysia. The target group of the survey was the paddy producing farmers. A structured questionnaire was used and data were collected through interview conducted by the regular enumerators of IADA authority under the direct supervision of IADA officials. IADA in North West Selangor consists of eight areas where total recorded paddy farmers are 10,300. A sample of 198 farmers cultivating a total of 577.53 hectares of paddy land were considered for this study. The samples were almost proportionately distributed among the eight areas based on the size of the irrigated land area. The samples within the area were selected randomly. Farmers' perceptions of impacts of climate change were measured using a 5-point scale with 1 as very low and 5 as very high impact. Data were analyzed under the framework of a descriptive model using tables, graphs, percentages and ratios, etc.

\section{NATURE AND IMPACTS OF CLIMATIC CHANGES IN MALAYSIA}

According to the United Nations Development Report, carbon dioxide emissions in Malaysia increased by 221\% during the period of 1990 to 2004; it is thus included in the list of 30 biggest greenhouse gas emitters (The Associated Press 2007). Liebman (2007) also mentioned that rapid growth in emissions has been occurred even though Malaysia ratified the Kyoto Protocol and has taken several initiatives to use renewable energy as well as ways to cut emissions. Currently Malaysia, with a population of 27 million, ranks as the 26th largest greenhouse gas emitter in the world; and it seems likely to move up the list quickly due to the growth rate of emissions.

In Malaysia, due to high greenhouse gas emissions the temperature is projected to rise by $0.3^{\circ} \mathrm{C}$ to $4.5^{\circ} \mathrm{C}$. Warmer temperature will cause sea level to rise about $95 \mathrm{~cm}$ over a hundred yearperiod. The changes in rainfall may fluctuate from about $-30 \%$ to $+30 \%$. This change will reduce crop yield and cause drought in many areas; and cultivation of some crops such as rubber, oil palm and cocoa may not be any more possible (NRS 2001). Another projection shows that maximum monthly precipitation will increase up to $51 \%$ in the states of Pahang, Kelantan and Terengganu, while the minimum precipitation will decrease ranging from $32 \%$ to $61 \%$ all over Peninsular Malaysia (NAHRIM 2006). However, the annual rainfall will increase up to $10 \%$ in 
Kelantan, Terengganu, Pahang and North West Coast, and decrease up to 5\% in Selangor and Johor. This variation of climatic factors will make the agricultural system vulnerable.

Temperature above $25^{\circ} \mathrm{C}$ may cause decline in grain mass and grain yield (Tashiro and Wardlaw 1989; Baker and Allen 1993). In Malaysia average temperature in rice growing areas is about $26^{\circ} \mathrm{C}$. Singh et al. (1996) reported that the actual farm yield of paddy in Malaysia vary from 3 - 5 tons per hectare as against the potential yield of 7.2 tons. It is also reported that paddy yield declined between $4.6 \%-6.1 \%$ per $1{ }^{\circ} \mathrm{C}$ temperature increase under the present $\mathrm{CO}_{2}$ level. In a recent study it has been found that a $1 \%$ increase in temperature leads to $3.44 \%$ decrease in current paddy yield, and $.03 \%$ decrease in paddy yield in next season. A regression analysis of the rainfall and paddy production reveals that a $1 \%$ increase in rainfall leads to $.12 \%$ decrease in current paddy yield, and .21\% decrease of paddy yield in next season (Alam et al. 2010b).

Tisdell (1996) reports that rainfall variability increases the level of environmental stress that affects the capability of the system to maintain productivity. Projection (NRS 2001) shows that given the $\mathrm{CO}_{2}(\mathrm{ppm})$ as 400 and variation in temperature as $0.3^{0} \mathrm{C}$ and above, variation of rainfall by more than $0.4 \%$ by the year of 2020 will cause reduction in paddy production and earnings of farmers (Table 1).

Table 1: Projection of Revenue Changes (RM) for Paddy Production with Variations of Temperature and Rainfall at Certain Level of $\mathrm{CO}_{2}$

\begin{tabular}{|c|c|c|c|}
\hline \multirow{4}{|c|}{ Year 2020 } \\
\hline & \multicolumn{3}{|c|}{ Variation in Temperature $\left({ }^{\mathbf{0}} \mathrm{C}\right)$} \\
\cline { 2 - 4 } & $\mathbf{0 . 3}$ & $\mathbf{0 . 8 5}$ & $\mathbf{1 . 4}$ \\
\hline $\begin{array}{c}\text { Variation in } \\
\text { Rainfall }\end{array}$ & \multicolumn{3}{|c|}{ Change in Revenue (RM/ Ha) } \\
\hline $\mathbf{1 4 \%}$ & -554.2 & -554.2 & -554.2 \\
\hline $\mathbf{7 \%}$ & -291.8 & -291.8 & -291.8 \\
\hline $\mathbf{0 . 4 \%}$ & 0 & 0 & 0 \\
\hline $\mathbf{0 \%}$ & 0 & 0 & 0 \\
\hline $\mathbf{- 0 . 4 \%}$ & 0 & 0 & 0 \\
\hline $\mathbf{- 7 \%}$ & -264.5 & -251.9 & -224.0 \\
\hline $\mathbf{- 1 4 \%}$ & -529.0 & -504.3 & -488.0 \\
\hline
\end{tabular}

* Revenue calculated as paddy price per 100kg Super Grade= RM55.00 \& Normal Grade $=$ RM51.69

Source: NRS 2001

Total yearly rainfall in Malaysia is increasing but its monthly variation is too high. The most vulnerable states in terms of fluctuation in rainfall and temperature are Sabah, Terengganu, Kelantan, Sarawak, Kedah, Perlis, and Perak (NAHRIM 2006). The effect of lower rainfall can be somehow controlled through introduction of proper irrigation system. But the problem of over rainfall at any particular time is not controllable. Over rainfall especially at the end of the crop cycle or at the maturity period, causes serious damages to crops. It is found that the most vulnerable group of people are the poor and hardcore poor engaged in agricultural activities and having relatively larger number of household members (NRS 2001). Since these farmers are dependent on agriculture, their family income declines with the decline in agricultural 
productivity and production. Change in climatic factors, therefore, affect directly and indirectly the social and economic sustainability of the farmers. Climatic changes cause crop damages leading to low productivity and high production cost, income losses to farmers, increase in seasonal unemployment rate, and increase in poverty level

Upon realization of this problem the Second National Agricultural Policy (1992-1997) was revised in 1998 and the Third National Agricultural Policy (1998-2010) was designed based on a vision of development of a dynamic agricultural sector focusing on an efficient market-led competitive growth. The principal aim of the Third National Agricultural Policy (1998-2010) is to maximize income of the stakeholders through optimal utilization of resources.

\section{DATA ANALYSIS AND RESULTS}

The climatic factors affect the social and economic sustainability of the farmers. Climatic change causes crop damages leading to low productivity and high production cost, income losses to farmers, increase in seasonal unemployment rate, and increase in poverty level. The survey data on the perceived impacts of climate change on the socioeconomic status of the paddy farmers in the study area have been analysed and discussed in this section.

\section{Perceived Socioeconomic Impacts of Climatic Change}

Several types of social and economic factors including population growth, poverty, income distribution, unemployment, health status, education level, gender inequality, hazardous location, access to resources and services including knowledge and technological means, and lack of political voice, etc. are directly and indirectly affected by climatic changes. However, in this analysis we focus on the direct and major impacts of climatic change on paddy farmers' socioeconomic status.

Table 2: Paddy Farmers' Perception on the Socioeconomic Impacts of Climatic Changes

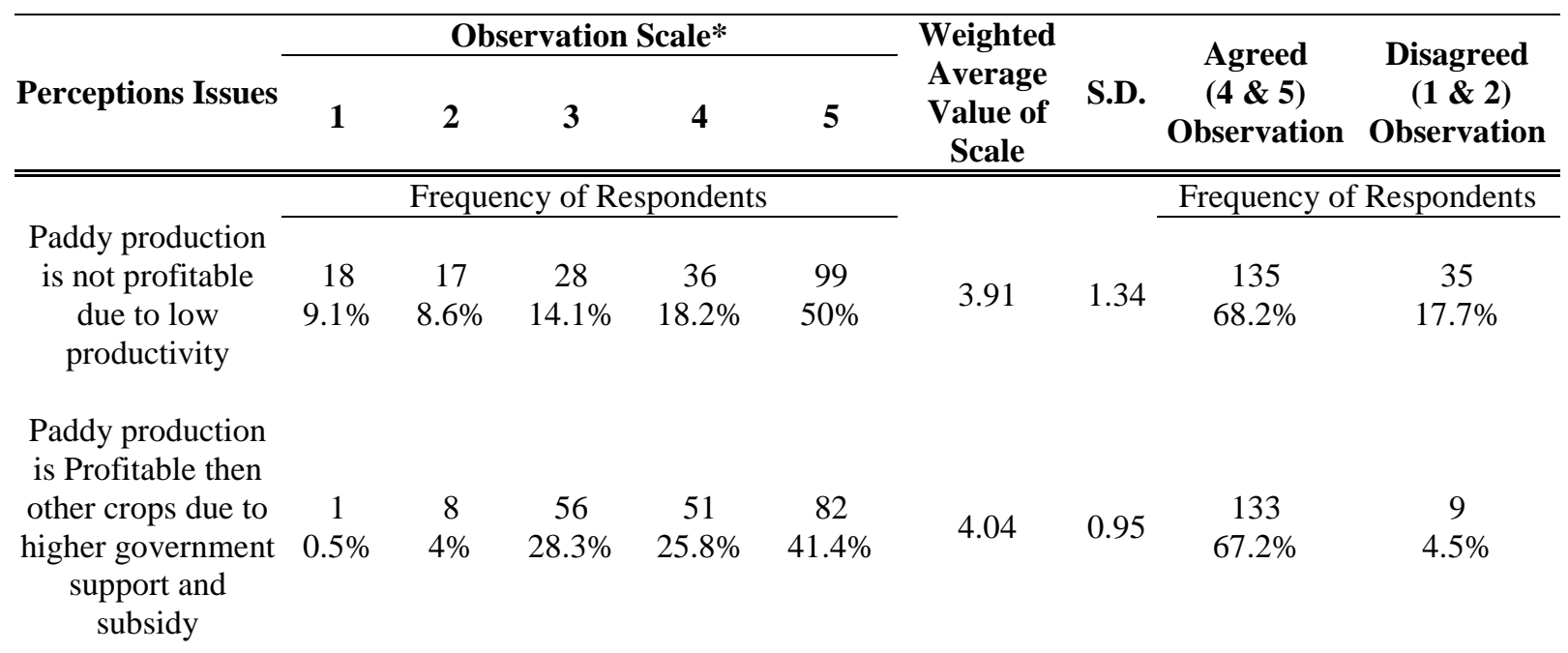




\begin{tabular}{|c|c|c|c|c|c|c|c|c|c|}
\hline $\begin{array}{l}\text { Climate related } \\
\text { factors- sunlight, } \\
\text { rainfall- cause } \\
\text { health problems }\end{array}$ & $\begin{array}{c}2 \\
1 \%\end{array}$ & $\begin{array}{c}9 \\
4.5 \%\end{array}$ & $\begin{array}{c}41 \\
20.7 \%\end{array}$ & $\begin{array}{c}70 \\
35.4 \%\end{array}$ & $\begin{array}{c}76 \\
38.4 \%\end{array}$ & 4.06 & 0.93 & $\begin{array}{c}146 \\
73.7 \%\end{array}$ & $\begin{array}{c}11 \\
5.6 \%\end{array}$ \\
\hline $\begin{array}{l}\text { Part time work in } \\
\text { Agriculture is } \\
\text { more profitable } \\
\text { than full time }\end{array}$ & $\begin{array}{c}24 \\
12.1 \%\end{array}$ & $\begin{array}{c}13 \\
6.6 \%\end{array}$ & $\begin{array}{c}49 \\
24.7 \%\end{array}$ & $\begin{array}{c}85 \\
42.9 \%\end{array}$ & $2713.6 \%$ & 3.39 & 1.17 & $\begin{array}{c}112 \\
56.6 \%\end{array}$ & $\begin{array}{c}37 \\
18.7 \%\end{array}$ \\
\hline
\end{tabular}

*Scale: 1 = Strongly Disagree, 2 = Disagree, 3 = No Comment, 4 = Agree, 5 = Strongly Agree

Source : Survey Data

\section{Size and Distribution of Income and Profitability of Paddy Cultivation}

From the IADA records it is observed that currently $38.4 \%$ of households or $44.7 \%$ population of the study area have per capita income below RM 6,387; and $65.7 \%$ of the households or $72.8 \%$ of the population have per capita income below RM 12,775. There are on average 4.74 members per household in the study area. IADA has the target to ensure an annual income of RM 24,000 for each farmer from paddy production. But over $68 \%$ of the paddy farmers either agree or strongly agree that the paddy cultivation is no longer profitable because of low productivity. On the other hand $67 \%$ of them equally perceive that because of greater government subsidy and support paddy cultivation is still better than cultivation of other crops (Table 2).

Government subsidy for agricultural sector is increasing each year. The subsidies for urea and compound have been continuing since 1979. The incentive for land preparation and organic fertilizer has been continuing since 2007. Providing compound and urea fertilizer, and pesticide incentive was introduced in 2008 and is still continuing. However, unless the adverse effects of climatic change are not reduced or removed and productivity is increased, government support and subsidy cannot produce a sustainable and progressive paddy sector, in particular, and the agriculture in general.

An analysis of the distribution of income shows that there is a high inequality of income distribution among the paddy farmers and farming population in this area. Top $20 \%$ receive of the farmers receive $46.8 \%$ of total income and the bottom 40 percent receive only $16.2 \%$ (Table 3) Using the Inequality Ratio - also known as Kuznets ratio - income of top $20 \%$ to income of bottom $40 \%$ we find the value $=2.88(46.8 / 16.2)$, meaning that the degree of inequality at farmhousehold level is nearly three times. However if we measure the degree of inequality in terms of population we get through interpolation : bottom $40 \%$ of the population has roughly $14 \%$ of total income and the top $20 \%$ has roughly $46 \%$ and the degree of inequality will be roughly 3.3 (46/14). The degree of inequality is more because there are likely more population in the poorer farm-households and less population in richer farm-households.

Table 3: Distributions of Income among the Sample Farmers, 2009

\begin{tabular}{ccccccc}
\hline $\begin{array}{c}\text { Distributi } \\
\text { on }\end{array}$ & $\begin{array}{c}\text { No. of } \\
\text { Household Population }\end{array}$ & $\begin{array}{c}\text { No. of } \\
\text { Income }\end{array}$ & $\begin{array}{c}\text { Cumulative } \\
\text { Income }\end{array}$ & $\begin{array}{c}\text { \% of } \\
\text { Cumulative }\end{array}$ & $\begin{array}{c}\text { \% of Cumulative } \begin{array}{c}\text { \% of Cumulative } \\
\text { Households }\end{array} \\
\text { Populations }\end{array}$ \\
\hline \hline
\end{tabular}




\begin{tabular}{lccccccc}
\hline & & \multicolumn{7}{c}{ Income } \\
\hline \hline $0-10 \%$ & 20 & 119 & 235381 & 235,381 & $2.1 \%$ & $10 \%$ & $13 \%$ \\
$10-20 \%$ & 40 & 110 & 388157 & 623,537 & $5.6 \%$ & $20 \%$ & $24 \%$ \\
$20-30 \%$ & 60 & 104 & 512654 & $1,136,191$ & $10.2 \%$ & $30 \%$ & $36 \%$ \\
$30-40 \%$ & 80 & 108 & 665646 & $1,801,837$ & $16.2 \%$ & $40 \%$ & $47 \%$ \\
$40-50 \%$ & 100 & 92 & 727728 & $2,529,565$ & $22.8 \%$ & $51 \%$ & $57 \%$ \\
$50-60 \%$ & 120 & 103 & 1062789 & $3,592,353$ & $32.4 \%$ & $61 \%$ & $68 \%$ \\
$60-70 \%$ & 140 & 73 & 937915 & $4,530,269$ & $40.8 \%$ & $71 \%$ & $76 \%$ \\
$70-80 \%$ & 160 & 79 & 1379380 & $5,909,649$ & $53.2 \%$ & $81 \%$ & $84 \%$ \\
$80-90 \%$ & 180 & 82 & 1956930 & $7,866,579$ & $70.9 \%$ & $91 \%$ & $93 \%$ \\
$90-100 \%$ & 198 & 68 & 3235588 & $11,102,167$ & $100.0 \%$ & $100 \%$ & $100 \%$ \\
\hline
\end{tabular}

Source: Survey Data

The calculated Gini coefficient of 0.443 (average of the ratios of each \% of income over $\%$ of population) of the Lorenz Curve equally suggests that there is a high degree of income inequality among the paddy farmers in the study area (Fig. 1).

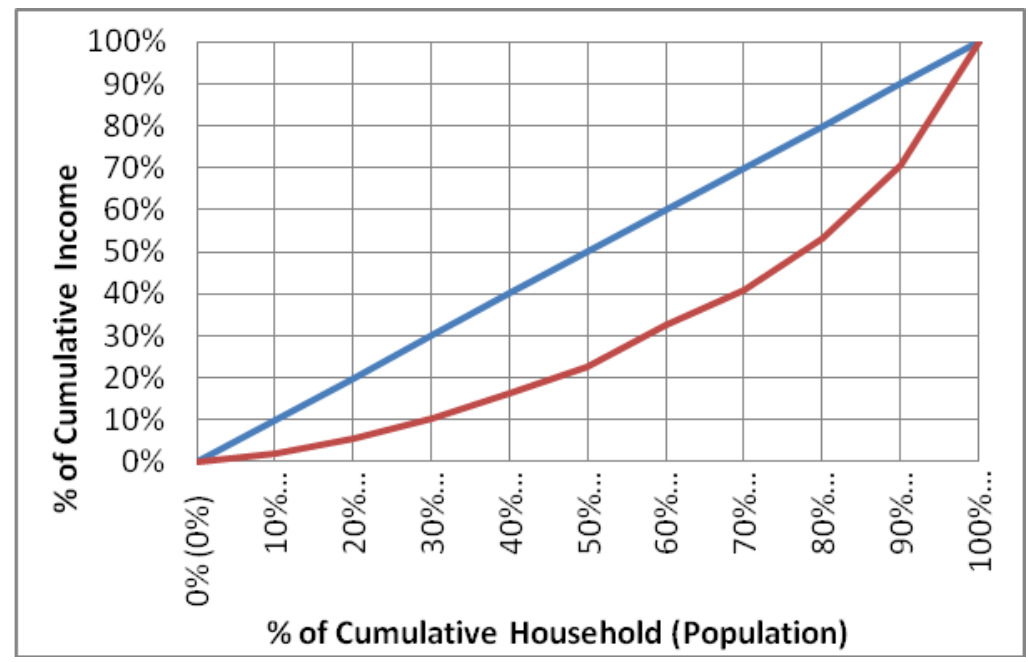

Figure 1: Lorenz Curve or Income Inequality among Farmers

\section{Impacts on Farmers' Health}

Climate change has many negative impacts on human health, because a wide range of diseases vector-borne, water-borne and respiratory - have links to climatic changes. Climatic factors are directly connected to incidences of diarrhoea, skin disease, malaria, kala-azar, dengue fever and other illnesses. Other health-relevant factors, such as dehydration, malnutrition, and heat stress, especially among elder farmers, are closely linked to climate factors and food production. Nearly $74 \%$ of the sample farmers either feel or strongly feel that they are having health problems due to changes in the climatic factors (Table 2).

\section{Interest in Part-Time Engagement in Farming}


Due to climate change farmers' active involvement in agriculture is declining. Currently, $18.7 \%$ of the farmers do not prefer the agriculture, and $17.2 \%$ are engaged in agriculture on part time basis. However, only $18.7 \%$ perceive that full time engagement in agriculture is more profitable than part time engagement. However, nearly $57 \%$ of the respondents support part time engagement for more family earnings / income (Table 3). That indicates, many farmers are searching for off farm job and trying to reduce their involvement in agriculture from full time to part time engagement. They feel off farm employment has scope for more income earning.

\section{RECOMMENDATION AND POLICY ACTIONS}

Change in climatic factors is a continuous and long term process. Its effects and solutions are similarly a long time and a pains-taking process. It is also widely accepted that strict mitigation efforts alone will not be sufficient to avoid significant impacts of climatic change (IPCC 2007). It is therefore important to balance between measures against the causes of climatic change and measures to cope with its adverse effects (Stern 2007, Pielke et al. 2007).

Climatic factors are exogenous and uncontrollable variables, only adaptation with the changing nature of these factors is the way to cope with the problem. Adaptation at the local level is essential for comprehensive and effective development and implementation of programs including ecological, social and institutional systems on the ground. Agricultural adaptation options need to ensure through technological developments, government programs, farm production practices, and farm financial management (Smit and Skinner 2002). Technological adaptation is most important to deal with the problem in the long run. To remedy the problem, improvement of technology needs to reach such a level to control the climate factors. Based on the high uncertainty of such technological advancement in short period, adaptation related technology is more important as a short term solution, such as, development of resource management based technique: protect crops from excessive rainfall, solve water logging problems etc., crop development: verities of crops, rainfall tolerant plants etc., crop cycle change: shift the timing of crop cycle, reduction in the timing of crop cycle etc.

Government needs to carefully define its subsidy supports and incentive programs to influence farm-level production practices and financial management. Farther, these policies need to define and ensure the compensation and insurance facility for the affected groups - individual farmer or farm. Proactive adaptation policies need to be developed. In climate change related planning processes it needs to take into account that stakeholders are sufficiently informed about its need and possible strategies (Eisenack and Kropp 2006; Eisenack, Tekken and Kropp 2007).

The production and farm management practices need to be updated with the changes in climatic factors. They should understand the crop rotation, crop portfolio, and crop substitutions. They have to take all precautions against all the uncertainties like low rainfall and heavy rainfall. For that reason, they should take initiative for crop sharing, forward rating, hedging, and insurance etc. 
Mitigation or adaptation to the climatic changes is an issue that concerns all sectors and levels of political, administrative, economic and everyday life. To effectively cope with the climate change, cooperation is necessary across regions, countries, sectors and administrative levels. Relevant actors need to be aware of the need for cooperation for long-term benefits instead of focusing only on short-term and individual country interest.

\section{CONCLUSION}

Like in many other countries, changes in climatic factors have negative impacts on productivity of paddy cultivation in the study area. Projections of climatic change and its adverse effects on paddy productivity and socioeconomic status of the farmers have been found alarming. As many as $68 \%$ of the farmers strongly perceive that climatic changes have caused profitability of paddy cultivation to decline. Many farmers are trying to reduce their involvement with agriculture. As a result, as many as $56.6 \%$ are inclined to prefer part-time to full-time engagement in paddy cultivation. Among the paddy producing farmers, $68.2 \%$ agree that paddy production is not much profitable due to low productivity, but $67.2 \%$ of farmers feel that because of heavy government subsidies and incentives paddy cultivation it is still better and more profitable than production of other crops. But it needs increase in productivity and growth to make the sector viable and sustainable.

A Kuznets ratio of 2.88 and the Gini coefficient of 0.443 suggest that there is a high level of income inequality among the paddy farmers in the study area. To generalize the findings of the study for overall paddy sector in Malaysia, same study needs to be conducted in several paddy producing areas.

\section{References}

Alam, M.M. \& Siwar, C. 2009. Socioeconomic Impacts and Vulnerability of Climate Change on Farming Community: A Study on Malaysian Perspective. Proceedings of the 3rd International Conference on Social Sciences and Humanities. National University of Malaysia, Dec 2-3, Malaysia.

Alam, M.M., Siwar, C. \& Toriman, M.E. 2009. Rainfall variability, water and agricultural sustainability: a socioeconomic study of vulnerability and adaptation of climate change, case of paddy farming in North West Selangor, Malaysia. Presented in the International Conference on Water, Environment, Energy and Society. Agra University, India, Jun 2830.

Alam, M.M., Siwar, C. \& Toriman, M.E. 2010a. Socioeconomic Study of Climate Change: An Assessment of Agriculture and Livelihood Sustainability on Paddy Farming in Malaysia. LAP Lambert Academic Publishing: Saarbrucken.

Alam, M.M., Talib, B., Siwar, C., Toriman, M.E. 2010b. The Impacts of Climate Change on Paddy Production in Malaysia: Case of Paddy Farming in North West Selangor. Proceedings of the international conference of the 4th International Malaysia- Thailand Conference on South Asian Studies. National University of Malaysia, Malaysia, Mar 2526. 
Baker, J.T. \& Allen, Jr. L.H. 1993. Contrasting crop species responses to $\mathrm{CO}_{2}$ and temperature: rice, soybean and citrus. Vegetatio 104/105: 239-260.

Behringer, J., Buerki, R. \& Fuhrer, J. 2000. Participatory integrated assessment of adaptation to climate change in Alpine tourism and mountain agriculture. Integrated Assessment 1: 331-338.

Brown, K., Few, R. \& Tompkins, E.L. 2007. Climate change and coastal management decisions: insights from Christchurch Bay, Coastal Management 35(2-3): 255-270.

Daly, H. \& Cobb, J. 1990. For the Common Good. Green Print Publishing: London.

Eisenack, K. \& Kropp, J. 2006. Regional stakeholder perceptions of climate change: Baltic case study screening, ASTRA document, Potsdam.

Eisenack, K., Tekken, V. \& Kropp, J. 2007. Stakeholder Perceptions of climate change in the Baltic Sea Region. Coastline Reports 8: 245-255.

FAO. 2003. World Agriculture towards 2015/2030: An FAO Perspective. Rome: Food and Agriculture Organisation of the United Nations.

Homer-Dixon, T. 1992. Environment al Change and Acute Conflict, International Security 16 (2): 31-102.

IADA (Integrated Agricultural Development Area). 2009. Internal Unpublished Data from the record of North West Selangor, Malaysia, March.

IPCC (Intergovernmental Panel on Climate Change). 2007. Climate Change 2007: The Physical Science Basis. Intergovernmental Panel on Climate Change. Cambridge University Press: Cambridge, U.K.

Klein, R.J.T., Schipper, E.L.F. \& Dessai, S. 2005. Integrating mitigation and adaptation into climate and development policy: three research questions. Environmental Science and Policy 8(6): 579-588.

Liebman, Bob. 2007. Malaysia Leads the World in Greenhouse Gas Emission Growth Rate. Curb Global Warming. Nov 29 (online) http://curbglobalwarmingblog.blogspot.com/2007/11/malaysia-leads-world-ingreenhouse-gas.html (Oct 1 2009).

NAHRIM. 2006. Final Report: Study of the Impact of Climate Change on the hydrologic Regime and Water Resources of Peninsular Malaysia, National Hydraulic Research Institute of Malaysia (NAHRIM) and California Hydrologic Research Laboratory (CHRL), Malaysia.

Ninth Malaysia Plan. 2006. Ninth Malaysia Plan 2006-2010. The Economic Planning Unit, Prime Minister's Department, Putrajaya, Malaysia.

NRS. 2001. National Response Strategies to Climate Change. Ministry of Science, Technology and the Environment, Malaysia.

Pielke, R., Prins, G., Rayner, S. \& Sarewitz, D. 2007. Lifting the taboo on adaptation. Nature 445(7128): 597-598.

Reilly, J. 1999. Climate Change: Can Agriculture Adapt?. Choices 14(1): 4-8.

Schimmelpfenning, D. 1996. Uncertainty in Economic Models of Climate Change Impacts. Climatic Change 33(2): 213-34.

Singh, S., Amartalingam, R., Wan Harun, W.S. \& Islam, M.T. 1996. Simulated impact of climate change on rice production in Peninsular Malaysia. Proceeding of National Conference on Climate Change. pp. 41-49, UPM, Malaysia. 
Siwar, C., Alam, M.M., Murad, M.W. \& Al-amin, A.Q. 2009a. Impacts of climate change on agricultural sustainability and poverty in Malaysia. Proceeding of $10^{\text {th }}$ International Business Research Conference. Dubai. UAE. Apr 16-17. (online) http://www.wbiconpro.com/15[1].Siwar.pdf (Jun 15 2009).

Siwar, C., Alam, M.M., Murad, M.W. \& Al-amin, A.Q. 2009b. A review of the linkages between climate change, agricultural sustainability and poverty in Malaysia. International Review of Business Research Papers 5(6): 309-321 (online) http://www.bizresearchpapers.com/23.\%20Siwar.pdf (Dec 1 2009)

Smit, B. \& Skinner, M.W. 2002. Adaptation options in agriculture to climate change: a typology. Mitigation and Adaptation Strategies for Global Change 7: 85-114.

Stern, N. 2007. The Economics of Climate Change: The Stern Review. Cambridge University Press: Cambridge.

Tashiro, T. \& Wardlaw, I.F. 1989. A comparison of the effect of high temperature on grain development in wheat and rice. Annals of Botany 64: 59-65.

The Associated Press. 2007. Malaysian Growth of Carbon Emissions Highest in the World, UN Says. The Irrawaddy. Nov 29. (online) http://www.irrawaddy.org/article.php?art_id=9454 (Oct 1 2009).

Tisdell, C. 1996, Economic indicators to assess the sustainability of conservation farming projects: An evaluation. Agriculture, Ecosystems and Environment 57(2): 117-131. United Nations. 1997. Critical Trends: Global Changes and Sustainable Development. UN Department for Policy Coordination and Sustainable Development, New York. 